Niniejsza publikacja jest dostępna na licencji Creative Commons. Uznanie autorstwa-Użycie niekomercyjne-Bez utworów zależnych 3.0 Polska. Pewne prawa zastrzeżone na rzecz autora. Zezwala się na wykorzystanie publikacji zgodnie z licencja - pod warunkiem zachowania niniejszej informacji licencyjnej oraz wskazania autora jako wtaściciela praw do tekstu. Treść licencji jest dostęna na stronie: http:// creativecommons.org/licenses/by-nc-nd/3.0/ pl/

Lingwistyka Stosowana 17: 2/ 2016, 139-160

Marcin MOŻDŻONEK

Uniwersytet Warszawski

\title{
Zarys modelu (rzeczywistej) komunikacji międzyludzkiej w odniesieniu do (rzeczywistych) języków ludzkich i (rzeczywistej) kultury ludzkiej
}

\begin{abstract}
:
An outline of (real) inter-human communication model in relation to (real) human languages and (real) human culture

In the present article an answer to the question of how inter-human communication functions shall be proposed. A detailed research throughout the questions of language, culture and knowledge has been conducted in order to outline a model of inter-human communication that relates to the aforementioned language, culture and knowledge. The latter three have been perceived from the anthropocentric perspective which entails considering (real) human language(s) as well as knowledge(s) and culture(s) as very individual items thus making them individual phenomena of each and every human being. Therefore, it needs to be assumed that communication between two individuals shall be of a kind of two individual languages, cultures and pieces of knowledge. In the latter part of the article two models shall be proposed: a simplified one, and a detailed one, both of which outline and adhere to the anthropocentric perspective. As the names might suggest, the first of the models demonstrates only a narrow context whereas the detailed one takes a number of variables into account.
\end{abstract}

What can linguists learn about the human mind by studying a language?

D. Sandra

\section{Wstęp}

Pytanie, które posłużyło za motto do tego tekstu, zostało zadane już w 1998 r. przez D. Sandra w artykule pt. "What linguists can and can't tell you about the human mind: A reply to Croft". Mogłoby się wydawać, że z jednej strony lingwistyka, w szczególności stosowana, nie zajmuje się tymi kwestiami. Mogłoby się także wydawać, iż jest to raczej sfera zainteresowań neurolingwistyki. Pisali na ten temat choćby G. Roth (1996, 2003); E. Linz (2002); J. E. Gorzelańczyk (2003). Do jednego z ciekawszych wniosków doszła z kolei J. Aitchison w swojej publikacji pt. Ssak który mówi (1991). Przeprowadziła ona badanie na małpach, które polegało na nauczeniu tego gatunku zwierząt pewnych znaków i sygnałów (przede wszystkim migania). Chciała mianowicie sprawdzić, czy „badani” wytworzą własny system komunikatów w oparciu o kod, którego zostały 
nauczone. Jak wynika z obserwacji poczynionych przez D. Sandra, kreatywne wykorzystanie języka jest właściwe tylko człowiekowi.

Wracając, jednakże, do przedmiotowego pytania: czego językoznawcy mogą się dowiedzieć na temat umysłu/ mózgu ludzkiego badając język? Z jednej strony odpowiedź nasuwa się sama, $z$ drugiej jednak, warto zdefiniować czym jest, i jak należy rozumieć język, a co za tym idzie, i kultura (jak wykażę poniżej, są to dwie rzeczy ze sobą nierozerwalnie związane). Na podstawie definicji tych dwóch pojęć, a także zarysu tego, czym jest wiedza, przedstawię dwa modele rzeczywistej komunikacji międzyludzkiej uproszczony i ,rozszerzony”.

\section{1. (Rzeczywisty) język}

Rozważania na temat języka, jego samego, jego istoty oraz, mówiąc wprost, czym właściwie jest, toczą się już od niepamiętnych czasów. Przypuszcza się z dużą dozą prawdopodobieństwa, iż pierwszą gramatykę funkcjonalną, czy też opisową, stworzył Panini żyjący na przełomie V i IV w. p.n.e. na terenie dzisiejszych Indii. W europejskiej starożytności prowadzono dyskusje na temat tego, czy językiem rządzą anomalie, czy też zachowuje się on w sposób logiczny. W toku historii, gdy granice się przesuwały (a właściwie w większości przypadków były przesuwane), królowie odchodzili i przychodzili, spory na temat język nieco przygasły, choć nie wygasły zupełnie.

Ponownym większym zainteresowaniem językoznawstwo zaczęło się cieszyć za sprawą niemieckiego filozofa, Wilhelma von Humboldta. Zgodnie z określeniem, którego użył F. Schlegel, zajmował się on językoznawstwem historyczno-porównawczym. Po nim nastąpiła era młodogramatyków, którzy, choć mieli swoje zasługi dla rozwoju światowego językoznawstwa, język pragnęli obserwować i badać jedynie z perspektywy nauk przyrodniczo-filozoficznych.

Prawdziwy rozwój w pojmowaniu języka, jego istoty i znaczenia ropoczął sie dopiero za sprawą strukturalizmu. To właśnie w tym czasie pojawia się twierdzenie o znakach językowych, trójpodział języka na language-langue-parole, dokonany przez Ferdinanda de Saussure'a. W tym samym czasie żyło wielu wybitnych lingwistów. Warto wymienić choćby Sapira, Trubeckiego i, nieco późniejszego, Jakobsona.

W tym miejscu wydaje mi się, iż należałoby skupić się na rodzimym językoznawcy, który tworzył w tym samym czasie co F. de Saussure, a na pewno znał jego prace na temat języka. Chodzi mianowicie o Jana Baudouin de Courtenay'a. Jako pierwszy zaczął postrzegać język jako coś indywidualnego, jako wrodzoną i przynależną tylko jednostce właściwość człowieka:

Tak np. odróżniamy indywiduum w przeciwstawieniu do plemienia, do narodu; a więc z naszego stanowiska będziemy mieli język indywidualny i język plemienia albo narodu, rozwój indywidualno-językowy w różnicy od historii języka całego plemienia lub narodu (J.N. Baudouin de Courtenay 1974: 181).

Z kolei w jednej ze swoich późniejszych prac pisał: „Język istnieje tylko w mózgach indywidualnych, tylko w duszach, tylko w psychikach indywiduów, czyli osobników, składających się na daną społeczność językową (...)" (J.N. Baudouin de Courtenay 1974). 
Baudouin de Courtenay niestety nie rozwijał później swojej tezy na temat języka, a co za tym idzie, została ona pominięta i/ lub zapomniana na długie dziesięciolecia. W tym czasie postrzegano język, jako formę abstrakcyjną, niejednokrotnie wprowadzając błędne myślenie na temat jego samego, a także i jego „reprezentacji”. Częstokroć uważa się, iż język ludzki istnieje jakby samoistnie, w oderwaniu od człowieka, w pewnym sensie niezależnie od niego. Nie jest to jednak prawdą.

Języki ludzie, rzeczywiste języki ludzkie, istnieją de facto w mózgach i umysłach poszczególnych jednostek ludzkich (zob. F. Grucza 1996, 1997, 2002, S.Grucza 2010, 2012c). To właśnie te idiolekty są prymarnymi, konstytutywnymi postaciami rzeczywistych języków:

Język ludzki jest czymś rzeczywiście istniejącym, ale czymś zatopionym tak bardzo głęboko w człowieku i czymś z nim tak mocno zespolonym, że nie sposób doń inaczej dotrzeć i inaczej go poznać, jak drogą rekonstrukcyjnej abstrakcji (F. Grucza 1993: 151).

Pamiętać należy również o tym, iż niejednokrotnie za język uznaje się jedynie jego wyobrażenie, tzn. sam model. Warto w tym miejscu odwołać się do koncepcji Chomsky’ego i jego idealnych mówców-słuchaczy. Twierdził on mianowicie, iż język należy postrzegać jako skończony i/ lub nieskończony zbiór zdań. Z kolei każde z nich ma postać skończoną i składa się z ograniczonej liczby elementów (zob. N. Chomsky 1962). Początkowo N. Chomsky traktował język jako byt istniejący niezależnie od człowieka. Dopiero w późniejszych latach zaczął wiązać zdolności komunikacyjne i językowe z poszczególnymi mówcami-słuchaczami, choć pierwotnie jedynie z ich idealną reprezentacją (idealnym mówcą-słuchaczem) (zob. N. Chomsky 1962, 1965, 1986, 1995, A. Derra 2007).

Zgodnie z innym poglądem na temat języka, jest on - język, w stanie przenosić znaczenie lub, co gorsza, nadawać je czemuś. Odwoływał się do tego choćby, wspomniany już, Wilhelm von Humboldt:

(...) w każdym języku (...) tkwi charakterystyczny pogląd na świat. Tak jak pojedynczy dźwięk pośredniczy między przedmiotem a jednostką, tak cały język pośredniczy między człowiekiem a wewnętrznymi i zewnętrznymi uwarunkowaniami, które mają na niego wpływ (...), Przez ten sam akt, który pozwala człowiekowi wysnuć z siebie język, wprzęga się człowiek w język, a każdy język ·opasuje wokół narodu, do którego należy, krąg, z którego można wyjść o tyle tylko, o ile zarazem wkracza się w krąg innego języka (W. von Humboldt 1903-1936 t .7: 60).

Na ten temat wypowiada się również A. Wierzbicka, która już na wstępie do swojego artykułu „Uniwersalne pojęcia ludzkie i ich konfiguracje w różnych kulturach” stwierdza, co następuje:

Język jest narzędziem do wyrażania znaczeń. Myślimy, czujemy, postrzegamy - dążymy do wyrażenia naszych myśli, uczuć i spostrzeżeń. Zazwyczaj - choć nie jest to reguła - wyrażamy je, ponieważ pragniemy dzielić je z innymi ludźmi. Język jest nam także potrzebny do wyrażenia naszych myśli - często do ich uporządkowania(...) (A.Wierzbicka1991: 1).

Warto także przytoczyć zdanie trzech innych lingwistów, którzy wypowiadali się na temat języka oraz tego, iż może przenosić on znaczenie. Najpierw, przyjrzyjmy się zdaniu, do pewnego stopnia, przeciwnemu temu A. Wierzbickiej: 
Język nie jest tylko odtwarzającym instrumentem używanym do wyrażania naszych myśli, raczej jest tym, co nadaje im kształt, jest programem i przewodnikiem w umysłowej działalności człowieka (...) (B. Whorf 1982: 213-214).

Z kolei J. Bartmiński wypowiada się na temat języka i tego, co jest w nim zawarte w następujący sposób:

(...) To obraz "językowy" będący własnością wspólnotową (podkreślenie M. Możdżonek) jest najważniejszy, bo zawiera w sobie system wartości wynikający z doświadczeń historycznych całej wspólnoty językowej (...), W języku są zmagazynowane takie wytwory działań kulturowo-językowych od najprostszych formuł etykiety grzecznościowej (...), poprzez tzw. skrzydlate słowa, po całe wzorce wypowiedzi (gatunki mowy) przystosowane do okoliczności i dostosowane do intencji nadawcy (...) (J. Bartmiński 2007: 25).

Ostatnim z lingwistów, którego chciałbym w tym miejscu przytoczyć, podzielającym pogląd, iż język jest w stanie przenosić znaczenie, czy nawet kształtować rzeczywistość, jest E. Sapir. Pisze on mianowicie:

Język to „przewodnik po rzeczywistości społecznej”. (...) Istoty ludzkie nie żyją wyłącznie w świecie obiektywnym (...), ale w znacznym stopniu zdanie są na łaskę tego języka, który stał się środkiem porozumiewania w ich społeczeństwie. (...) Światy w których żyją różne społeczeństwa to światy odrębne, a nie po prostu ten sam świat, któremu przylepiono różne etykietki (E. Sapir 1978: 162).

Z jednej strony są to zdania, z którymi ciężko się nie zgodzić, z drugiej jednak, z tymi samymi opiniami po prostu nie sposób się jednoznacznie zgodzić. By lepiej pojąć na czym ten paradoks polega, przyjrzyjmy się temu, o czym mówią wymienieni autorzy. Każdy z nich odwołuje się do języka. W ich rozumieniu, jak można domniemywać, język posiada formę abstrakcyjną, by nie powiedzieć idealna, która jest zupełnie niezależna od człowieka, a jedyne punkty styczne między mówcą-słuchaczem i językiem są takie, że mówca-słuchacz posługuje się owym językiem, tak jakby korzystając z niego tylko w określonych sytuacjach. Mianowicie, tylko w sytuacjach komunikacyjnych.

Nim przejdziemy do funkcji jakie pełnią rzeczywiste języki ludzkie, poświęćmy jeszcze chwilę na rozróżnienie języka od jego idealnej reprezentacji. „Język i myśl rodzą się w umyśle (...) Ludzka wiedza i rozumienie nie pochodzą z indukcji. Raczej uaktywnione w wyniku odpowiedniego doświadczenia, wzrastają w umyśle w oparciu o biologiczną bazę (...)" (N. Chomsky 1986: 25). Jest to zdanie podzielane m.in. przez F. Gruczę (1997: 11), który uważa, że: „(...) języki ludzkie w ogóle nie istnieją na zewnątrz konkretnych ludzi".

Przyjmując takie założenie za prawdziwe, warto rozdzielić dwie istotne rzeczy (rzeczywisty) język ludzki od jego (idealnego) modelu. W tej drugiej kwestii wypowiadają się przytoczeni powyżej Bartmiński, Humboldt, Sapir, Whorf i Wierzbicka. Język nie jest w stanie wyrażać znaczeń, pośredniczyć między człowiekiem, a zewnętrznymi uwarunkowaniami, nie jest także wyrażającym instrumentem do przekazywania myśli, nie zawiera on doświadczeń kulturowo-historycznych, ani nie jest przewodnikiem po rzeczywistości społecznej. $Z$ jednej prostej przyczyny - nie może nimi być, gdyż wtedy musiałby istnieć niezależnie od człowieka. Szczególnie, że musiałby spełniać wszystkie przytoczone powyżej funkcje, a i pewnie wiele, wiele więcej. 
Rzeczywisty język, jak pisze Chomsky, powstaje w mózgu człowieka i, jak dopowiada F. Grucza, jest jego konstytutywnym współczynnikiem. Oznacza to, mówiąc wprost, że o języku nie można mówić „tak ogólnie”, gdyż „tak ogólny” język nie istnieje, ponieważ istnieć nie może. O języku należy zatem wypowiadać się tylko w odniesieniu do konkretnych jego użytkowników, mówców-słuchaczy.

Spośród wymienionych, najbliższym tej koncepcji był E. Sapir stwierdzając, iż „Światy w których żyją różne społeczeństwa to światy odrębne, a nie po prostu ten sam świat, któremu przylepiono różne etykietki” (E. Sapir 1978: 162). Należy zauważyć, że już samo to stwierdzenie dotyczyło przede wszystkim różnic pomiędzy społeczeństwami. W swoich późniejszych badaniach E. Sapir nie doprecyzował tej tezy, a co za tym idzie, nie doszedł do logicznej konkluzji:

Tak, jak nie ma dwóch całkiem identycznych osób, tak nie ma też dwóch całkiem identycznych idiolektów. Jednocześnie nie ma też dwóch idiolektów całkiem różnych - każdy jest pod jakimś względem podobny do każdego innego, choć oczywiście pod różnymi względami i w różnej mierze (F. Grucza 2002: 40).

Skoro zatem język jest konstytutywną własnością każdego jego użytkownika oraz można go rozpatrywać jedynie w odniesieniu do konkretnego mówcy-słuchacza, to w jaki sposób należy rozumieć sformułowania takie jak ,język polski” czy ,język niemiecki”. W ogromnym uproszczeniu można powiedzieć, że jest to język wszystkich Polaków, czy język wszystkich Niemców. Jednakże oznaczałoby to, iż każdy członek takiej społeczności albo posługiwałby się własnym idiolektem i sztucznie utworzonym comunilektem (wspólnym lektem, którego akwizycja odbywałaby się prawdopodobnie na poziomie edukacji szkolnej lub wcześniej), albo każdy członek wspomnianej społeczności posługiwałby się tym samym idiolektem, a co za tym idzie, wszyscy posiadaliby tę samą idiokluture, idiowiedze, itp.

Oba przedstawione powyżej scenariusze wydają się równie nieprawdopodobne. W pierwszym przypadku oznaczałoby to, iż od każdego człowieka należałoby oczekiwać znajomości przynajmniej dwóch lektów - idiolektu i communilektu, by móc się w ogóle komunikować i by mógł on stanowić o sobie. Z kolei w drugim przypadku, oznaczałoby to, że wszyscy członkowie danej społeczności posiadają dokładnie te same doświadczenia, zdolności do posługiwania się lektem, w pewnym sensie stanowiliby oni wtedy jeden organizm.

Biorąc powyższe pod uwagę, należy z całą stanowczością stwierdzić, iż jedynym sposobem mówienia o np. języku polskim, jest uznanie go za abstrakcyjny (idealny) wzorzec językowy, podobny do tego omawianego powyżej. Warto w tym miejscu poczynić jeszcze pewną uwagę. Jeśli potraktujemy nacjolekt, jako zbiór elementów wspólnych dla wszystkich mówców-słuchaczy posługujących się tymże, osiągniemy, zdawać by się mogło, efekt odwrotny do zamierzonego, gdyż musielibyśmy uznać ów nacjolekt za wyjątkowo słabo rozwinięty. Wszystkie elementy styczne znalazłyby się jedynie w „najuboższym” idiolekcie spośród wszystkich wziętych pod uwagę w danej grupie (zob. F. Grucza 2002).

Skoro zatem nie możemy uznać języka wspólnego dla danej społeczności (np. wspólnego dla wszystkich Francuzów, Anglików, Portugalczyków, itp.) za pewien rodzaj polilektu (dokładniej mówiąc za nacjolekt, jednakże nacjolekt jest pewną formą polilektu, tak jak we wzorze logicznym, że każdy nacjolekt jest polilektem, ale nie każdy 
polilekt jest nacjolektem), to warto zastanowić się, czym w takim razie jest ów polilekt. Podsumowując, ustaliliśmy dotychczas, iż język rzeczywisty, w pewnym uproszczeniu, jest idiolektem każdej konkretnej osoby. Jeśli zaś uznamy to za prawdziwe, to nie pozostaje nam nic innego, jak stwierdzić, że polilekt to zarówno logiczna suma idiolektów, jak również ich logiczny przekrój (zob. F. Grucza 1993). Początkowo może wydawać się to nieuzasadnione, by wszystkie brane pod uwagę idiolekty rozpatrywać zarówno pod kątem ich sumy, jak i przekroju logicznego. Wystarczy uzupełnić powyższą informację o fakt, iż w przekroju logicznym brane są pod uwage przede wszystkim fonemiki i gramatyki, zaś w sumie logicznej - leksyki (por. ibid.). Można to zilustrować w następujący sposób:

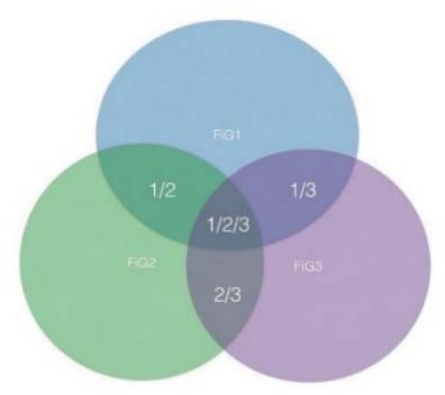

Schemat 1. Przekrój logiczny fonemik i gramatyk (FiG) możliwych polilektów skladających się $z$ do trzech idiolektów

Na przedstawionej powyżej grafice widać wyraźnie, iż w grupie fonemik i gramatyk nie da się jednoznacznie określić polilektu dla przedstawionej grupy trzech idiolektów. Część wspólną, a zarazem najmniejszy wspólny mianownik dla przedstawionego zbioru idiolektów stanowi pole oznaczone $1 / 2 / 3$. Warto zwrócić uwagę na fakt, iż możemy również mówić o polilektach w przypadku już dwóch spośród tych trzech idiolektów. Są to pola oznaczone jako $1 / 2 ; 1 / 3 ; 2 / 3$.

Sytuacja maluje się zgoła inaczej, kiedy mówimy o leksykach poszczególnych idiolektów. Przedstawić można to w następujący sposób:

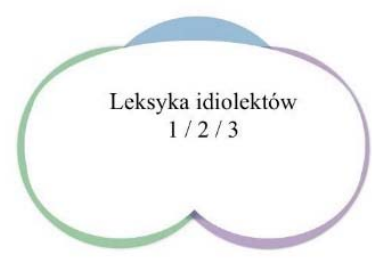

Schemat 2. Suma logiczna leksyk trzech idiolektów

W przeciwieństwie do gramatyk i fonemik idiolektów 1, 2, 3 ich leksyki się ze sobą sumują. Należy tutaj oczywiście poczynić założenie, że są to mówcy-słuchacze posługujący się jednym, abstrakcyjnym modelem języka narodowego, np. językiem polskim. 
Z przedstawionych powyżej uwag płynie prosty wniosek - każdy człowiek jest polilektalny, co nie znaczy, że jest wielojęzyczny. W innym kontekście, jednakże w podobnym tonie, wypowiadają się na ten temat H. Burger i B. Imhalsy: „(...) eine Sprache ist nich wirklich nur eine Sprache - es sind eine ganze Reihe von Sprachen, die sich zum Teil überlappen, zum Teil voneinander unterscheiden” (H. Burger/ B. Imhasly 1978: 14). Umiejętność posługiwania się np. językiem angielskim i językiem polskim (czyli bilingwizm) należy tutaj zdecydowanie odróżnić od tego, że każdy mówca-słuchacz posługuje się przynajmniej dwoma lektami. W dużej mierze będą się one różniły jedynie w warstwie leksykalnej, niekiedy również w warstwie fonemiczno-gramatycznej (domniemywać można, iż ta druga sytuacja jest rzadsza). Każdy posiada swój własny, indywidualny idiolekt, poza tym potrafi komunikować się z osobami zamieszkującymi to samo terytorium (np. dzielnicę), a zatem wykorzystuje do tego odpowiedni polilekt. Może on również znać lekt swojego miasta, województwa, swojej grupy rówieśniczej, swojego środowiska pracy (zob. F. Grucza 2002: 40). Możliwości w tym zakresie są nieskończone. Najważniejszy jednak wniosek z tego płynący, który pragnę tutaj szczególnie podkreślić, jest taki: każdy mówca-słuchacz jest polilektalny.

We wcześniejszej części niniejszego artykułu wspomniałem o funkcjach pełnionych przez język. Wyróżnia się trzyt radycyjne funkcje języka:

The traditional model of language as elucidated especially by Bühler was confined to those three functions - emotive, conative and referential - and the three apexes of this model - the first person of the addresser, the second person of the addressee., and the "third person," properly someone or something spoken of (R. Jakobson1960: 355).

Jednak R. Jakobson wyróżnia jeszcze kolejne cechy: (a) kontaktu (bądź, jak podaje za Malinowskim, fatyczna), (b) metajęzykowa, (c) poetycka.

Jego zdaniem, funkcja ekspresywna (in. emotywna) polega na tym, iż komunikat przekazywany jest bezpośrednio do adresata i skupia się na tym, co nadawca pragnie przekazać. Kolejna funkcja, konatywna, skupia się na odbiorcy komunikatu. Często w najczystszej formie znajduje odzwierciedlenie w takich formach gramatycznych jak wołacz i tryb rozkazujący. Z kolei funkcja poznawcza (in. oznaczająca i/ lub denotatywna) skupia się przede wszystkim na kontekście w jakim został nadany i odebrany komunikat.

Funkcja fatyczna, bądź jak ją nazywa Jakobson - kontaktu, skupia się właśnie na tym - na podtrzymaniu rozmowy/ korespondencji. Twierdzi on także, że jest to jedyna funkcja językowa, którą człowiek posiada od swoich narodzin - niemowlęta są w stanie wysyłać i odbierać sygnały, nim te zaczną nabierać znaczenia. Funkcja metajęzykowa, podobnie do fatycznej, służy utrzymaniu kontaktu, jednakże w zupełnie innym sensie. O ile funkcja fatyczna wykorzystywana jest tylko do nawiązania i podtrzymania kontaktu, o tyle zadaniem funkcja metajęzykowej jest sprawdzenie, czy adresat i nadawca komunikują się w tym samym kodzie, czyt. czy się rozumieją. Z kolei ostatnia, funkcja poetycka, skupia się na samym przekazie nadawanego komunikatu oraz na samym komunikacie. 


$\begin{array}{ccc} & \text { REFERENTIAL } & \\ & \text { POETIC } & \text { CONATIVE } \\ & \text { PHATIC } & \\ & \text { METALINGUAL }\end{array}$

Schemat 3. (por. Jakobson R. 1960)

Wszystkie wyżej opisane funkcje, można w skrócie opisać jednym sformułowaniem - funkcja komunikacyjna. Nie mylił się R. Jakobson, pisząc o powyższych funkcjach, jednakże nie miał też w pełni racji. Język, jako taki, nie pełni funkcji komunikacyjnej, a pełnią ją stworzone i ukonstytuowane przez mówców-słuchaczy wyrażenia językowe. Rzeczywisty język (ergo idiolekt każdego użytkownika języka) pełni za to inne, zdaje się ważniejsze, funkcje:
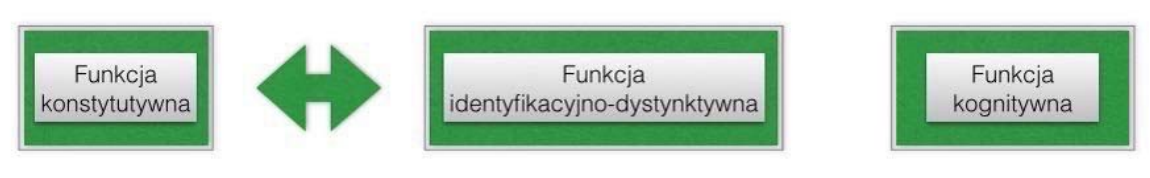

Schemat 4. Funkcje rzeczywistego języka ludzkiego na podstawie F. Gruczy (2002)

„(...) Rzeczywiste języki ludzkie (konkretne idiolekty) istnieją też o tyle, o ile istnieją ich właściciele (...) nie są pod żadnym względem bytami autonomicznymi" (F. Grucza 2002: 44). Właśnie dzięki temu ich podstawową funkcją jest funkcja konstytutywna. Konkretny rzeczywisty język, tzn. idiolekt konkretnego mówcy-słuchacza, istnieje tak długo, jak długo „istnieje” człowiek, który się nim posługuje.

Specjalnie zaznaczono wzajemną relację między funkcją konstytutywną a identyfikacyjno-dystynktywną. Jeśli istnieje konkretny mówca-słuchacz, to poszukiwać on będzie osób podobnych sobie (funkcja identyfikacyjna), to znaczy takich, których idiolekty są zbieżne pod kątem leksyki, a także fonemiczno-gramatycznym. Pozwala ona również odróżnić osoby, które do tej grupy nie należą (funkcja dystynktywna).

Funkcja kognitywna, choć w powyższym schemacie znajduje się na uboczu, nie jest w owej relacji mniej istotna. Każdy mówca-słuchacz ma możliwość poprzez wykorzystanie swojego idiolektu, idiowiedzy i idiokultury, aby rozszerzać ich zakresy. Może on rozwijać swoją tożsamość, także, a może przede wszystkim, tożsamość językową (zob. F. Grucza 2002: 44-46).

\section{2. (Rzeczywista) kultura i (rzeczywista) wiedza}

Rozważania nad kulturą, a także nad wiedzą, należy przede wszystkim rozpocząć od stwierdzenia spraw oczywistych: słowo „kultura” jest wyrazem wieloznacznym i jego znaczenie należy wpierw uściślić. Podobnie ma się kwestia wiedzy, choć nie jest ona wyrazem wieloznacznym, a pojęciem o wielu konotacjach znaczeniowych. 
Na samym początku wydaje się zasadnym by rozróżnić dwa pojęcia: „,kultura” i ,natura”. By zrozumieć, czym jest „,natura”, należy najpierw odpowiedzieć na pytanie, czym jest ,kultura”.

Samo słowo swoją etymologię wywodzi od łacińskiego rzeczownika cultura, -ae, który z kolei pochodzi od czasownika colere oznaczającego pierwotnie pielegnować, uprawiać, obrabiać (A.Brückner 1927). Warto zwrócić uwagę na fakt, iż po łacinie słowo cultura oznacza zarówno sam proces, jak i jego efekt (zob. S. Bonacchi 2009: 29). Prawdopodobnie również $\mathrm{z}$ tego powodu rozwinęło się $\mathrm{w}$ łacinie przenośne znaczenie tego słowa, które brzmi następująco: upiększać, pielęgnować duchowo i rozwijać (zob. G. Floros 2002). Do pierwotnego znaczenia kultury odwołuje się również S. Durring:

The word 'culture' itself, with its historical sense of 'cultivation', has a residually naturalising force: it is as if the formation of collectivities and individuals were like the cultivation of a crop (S. During 2005: 211).

Później pojęcie kultury rozwijało się na wielu różnych płaszczyznach, aż osiągnęło swój wieloznaczny charakter:

a) Kultur als/ Erscheinungsform des Geistes/ (romantische bzw. idealisti- sche Schule, biomorphe Zyklentheorie, theologischer Ansatz);

b) Kultur als/ Mittel zur Bewältigung von Lebensaufgaben/ (postdarwinis- tische Theorien, kulturpsychologischer und psychoanalitischer Ansatz, kulturan- thropologischer Ansatz);

c) Kultur als/ Gesamtheit der tradierten Formen gesellschaftlichen Zusam- menlebens/ (Kultursemantik, Kulturgeschichte, Historismus);

d) Kultur als/ kollektive Programmierung des Geistes/ (organisationsanth- ropologischer Ansatz);

e) Kultur als/ (Zeichen)system/ (semiotischer Ansatz, kultursystemische Theorie);

f) Kultur als/ Wertesystem/ (axiologischer Ansatz, kulturpolitischer Ansatz); g) Kultur als/ Text bzw. Hypertext/ (kulturinterpretativer Ansatz);

g) Kultur als/ Regelwerk/ (generativistischer Ansatz) (S. Bonacchi 2009: 31).

W naukach zajmujących się kulturą, kulturoznawstwie, cultural studies itp., kulturę postrzega się niejednokrotnie inaczej. Tak, np. I. Ang, przedstawia następującą definicję tego pojęcia:

"Culture" in cultural studies relates to the production and negotiation of meaning and value, and this is an ongoing, plural, often conflictive process taking place in all dimensions of social activity, be it at the workplace, in education, the media, in international relations, even in the hairdresser's salon. Culture is neither institutions nor texts nor behaviours, but the complex interactions between all of these (I. Ang 2005: 477).

Z kolei można ją także postrzegać w oddzieleniu od natury - jako tę część, którą człowiek sam sobie podporządkował. Podobnego zdania jest również S. During: „So nature is the outside of culture and society as that outside appears from inside, and in terms of, culture and society" (S.During 2005: 211). W skrócie można powiedzieć, że kultura jest wszystkim tym, co człowiek stworzył - zarówno wykorzystując do tego naturę, jak również dzięki niej. Kultura to także zdolności każdej jednostki, których nie otrzymała od natury (zob. S. Bonacchi 2010: 33). 
Zdaniem S. Pinkera, kultura wyłania się z naszego stylu życia i objawia się w nim jako indywidualne odkrycia i doświadczenia jednostek, a także w formie ustanawiania zwyczajów i tradycji, celem zorganizowania pracy i rozwiązywania konfliktów (zob. S. Pinker 2002). Z kolei H. Markus i M. Hamedani postrzegają to zjawisko jako „(...) patterns of representations, actions and artifacts that are distributed and spread by social interactions" (H.Markus/ M.Hamedani 2007: 11).

Zgoła przeciwnego, choć nie rozbieżnego, zdania w kwestii kultury zdaje się być M. Hager. Twierdzi on mianowicie, iż kultura to:

(...) a set of attitudes, behaviors, and symbols that a group of people have in common, and they are usually passed on from one generation to the next. Attitudes include beliefs (...) stereotypes, values, opinions, superstitions, and general knowledge. Behaviors incorporate many different traditions, norms, roles, practices, customs, habits, and fashions. Symbols represent things or ideas, and their meaning stems from the individuals who allot meaning to the symbols (M. Hager 2011: 3-4).

Wymienione powyżej teorie zdecydowanie wymagają pewnego doprecyzowania. Podobnie, jak w przypadku języka, tak i w przypadku kultury (również i wiedzy!) człowiek posiada odpowiednie narzędzia do wyrażania swoich emocji, pragnien, zamiarów, poglądów, dzielenia się swoją wiedzą, itp. Te narzędzia nazywać należy, ponownie, analogicznie do kwestii językowych, znakami. Wynika z tego zatem, że to, o czym pisali S. Pinker, H. Markus i M. Hamedani, a także S. During oraz M. Hager to znaki kulturowe. Nie można ani stereotypów, ani zachowań, ani tym bardziej wzajemnych relacji pomiędzy nimi i wieloma innymi dziedzinami nazywać kulturą, gdyż, co prawda należą one do dominium tejże i składają się na nią, lecz jej samej nie stanowią (zob. F. Grucza 2012a: 87). Chyba, że mówimy tutaj o potocznym lub uproszczonym rozumieniu pojęcia kultura.

Podobnie rzecz się ma z wiedzą człowieka. Nie istnieje ona ani w tekstach, ani w wyrażeniach, ani w słowach. Nie istnieje tam, ponieważ istnieć nie może. Gdyby istniała, oznaczałoby to, że to co ludzie wiedzą miałoby postać efemeryczną, ulotną, a co za tym idzie, jeśli wiedza zawarta $w$ produktach wiedzy nie byłaby w jakiś sposób magazynowana, człowiek by ją tracił. Analogicznie do języka i kultury, to co potocznie określa się wiedzą zawartą w książkach, tekstach, czy wyrażeniach, jest de facto znakiem wiedzy (zob. F. Grucza 1997).

Nim przejdziemy do określenia, czym jest rzeczywista kultura i rzeczywista wiedza, pochylmy się jeszcze nad samymi znakami kultury i znakami wiedzy. Każdy człowiek wyposażony jest w odpowiednią aparaturę wewnątrz swojego mózgu, która umożliwia mu zarówno odbieranie sygnatów kultury, jak i sygnałów wiedzy. Te pierwsze należy rozumieć jako nadawane przez kogoś znaki, które przenoszą pewne znaczenie, np. uniesiona w górę ręka z otwartą dłonią może oznaczać albo sytuację zagrożenia albo pożegnanie. Dzięki wspomnianemu narzędziu, jeden z mówców-słuchaczy jest w stanie nadać sygnał o konkretnym znaczeniu, a drugi go odebrać i zrozumieć. Podobnie jest $\mathrm{z}$ wiedzą ${ }^{1}$ - każdy człowiek może nadawać wiedzę, jak i ją odbierać. Zwróćmy jednak

\footnotetext{
${ }^{1}$ Wiedzę rozumieć tutaj będę zarówno jako nabytą w toku nauczania np. szkolnego, jak i taką wynikającą z doświadczeń jednostki.
} 
uwagę, iż wyrażenie ,przekazywać komuś swoją wiedzę”, choć w swym zamyśle poprawne, mija się zupełnie z prawdą. Człowiek nie jest w stanie przekazać drugiemu człowiekowi swojej wiedzy, a jedynie jest w stanie ją nadać, a druga osoba może ją odebrać. Kwestia zrozumienia i interpretacji jest dla obecnych rozważań bez znaczenia (zob. F. Grucza 1993, 1997, 2012a, 2012b, S. Bonacchi 2009, 2012).

Odwołajmy się zatem jeszcze raz do języka. Wspomniałem już, iż rzeczywisty język istnieje, bo tak jedynie istnieć może, w konkretnych osobach i stanowi ich konstytutywną właściwość. Kultura i wiedza nie różnią się pod tym względem. Rzeczywista kultura została zinternalizowana przez każdego człowieka. Składają się na nią rzeczywiste właściwości poszczególnych osób, a także wzajemne relacje pomiędzy nimi (zob. S. Bonacchi 2009: 38). Z kolei F. Grucza w następujący sposób opisuje idiokulturę (kulturę każdego poszczególnego człowieka):

Die Kultur eines Menschen macht eine bestimmte Teilmenge jener von ihm internalisierten Regeln und Mustern aus, die sein Verhalten, seine Aktivitäten bestimmten und/ oder die Ausführung dieser Aktivitäten möglich machen, ihn in die Lage versetzen, einerseits entsprechende „Dinge“ - sowohl geistige als auch materielle, als auch entsprechende Äußerungen hervorzubringen, und andererseits die auf ihn zukommende Umwelt (...) entsprechend zu erkennen, zu kategorisieren, zu interpretieren und (...) zu evaluieren, d.h. ihnen u.a. Sinn zu verleihen und ihren Sinn zu verstehen (F. Grucza 2000: 20).

Podobnie, jak w przypadku idiolektów, tak i w przypadku idiokultur istnieją kultury poszczególnych społeczności, czy grup. Kultura takiej grupy nazywa się, analogicznie, polikulturą. S. Bonacchi wyróżnia dwie możliwe interpretacje tego pojęcia:

- Włączające ${ }^{2}$ (intersektiv) - stanowiące przekrój logiczny wszystkich idiokultur, które z kolei składają się na jedną bądź więcej polikultur.

- Sumarycznie wyłączające ${ }^{3}$ (summarisch-extensiv) - to znaczy takie, w których poszczególne idiokultury wykluczają pozostałe idiokultury, a co za tym idzie polikultura powstaje na podstawie poszczególnego idiolektu. (zob. S. Bonacchi 2009: 40-41)

Logicznym zatem jest, że polikultura może, podług powyższego rozróżnienia, mieć charakter jedynie włączający. Podobnie jak w przekroju logicznym idiolektów składających się na polilekt/ -y, tak i w przypadku idiokultur składających się na polikulturę/ y, mamy do czynienia z sytuacją, kiedy w skład danej polikultury wchodzą wszystkie części wspólne obu lub więcej idiokultur. Można to zilustrować w sposób następujący:

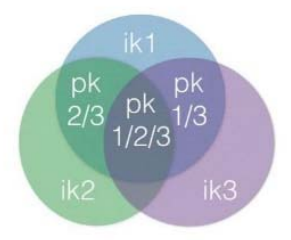

Schemat4. Przekrój logiczny idiokultur (ik) stanowiących stosowne polikultury (pk)

\footnotetext{
${ }^{2}$ Nazwa polska - M.M.

${ }^{3}$ Nazwa polska- M.M.
} 


\section{3. (Rzeczywista) komunikacja międzyludzka}

\subsection{Czym jest komunikacja?}

Już w pierwszym zdaniu należy zaznaczyć, iż człowiek komunikuje się z całym otoczeniem i całe otoczenie komunikuje się z nim. Nie ma tutaj znaczenia, czy są to inni ludzie, czy też „przyroda ożywiona” (jak zwierzęta, rośliny), czy „przyroda nieożywiona” (jak skały, kamienie, góry), czy przedmioty ruchome (jak np. samochody, telefony, lampy itp.), czy też przedmioty nieruchome (np. budynki). Należy to jednoznacznie podkreślić, iż człowiek zarówno w sposób językowy (werbalny), jak i para- i ekstrajęzykowy, a także kulturowy, para- i ekstrakulturowy, a również wiedzowy, para- i ekstrawiedzowy komunikuje się z całym otaczającym go w danej chwili światem i że ów otaczający go w danej chwili świat komunikuje się z nim (zob. F. Grucza 1992, 2012b: 337-341). Podobnego zdania jest S. Bahadir powołujący się na Göhringa i Watzlawicka: "This conviction reminds me of Watzlawick's assumption, to which Göhring (1998) refers, that we cannot communicate, i.e. that we communicate by just being and behaving (Watzlawick et al. 1967)" (S. Bahadır 2004: 808).

Niemniej, mimo poczynionej powyżej uwagi, nas interesować będzie przede wszystkim proces komunikacji zachodzący pomiędzy ludźmi - komunikacja międzyludzka.

Najprościej o komunikacji międzyludzkiej można powiedzieć, że oznacza ona tyle, co porozumieć się z kimś (zob. H.Burger/ B.Imhasly 1978: 15). W uproszczeniu polega ona na tym, że nadawca nadaje sygnał (dźwiękowy, graficzny, niewerbalny, etc.), który występuje w formie znaku (tzn. fonem, bądź zbiór fonemów, a także grafem, bądź zbiór grafemów, itp. zastępują sygnał) do odbiorcy. Znak zawsze osadzony jest w konstytucji (tj. kontekście sytuacyjnym) oraz w kontekście społeczno-kulturowym (zob. B.Z. Kielar 1988: 10-11). „(...) Bedeutungen von einzelnen Zeichen (Wörtern) können nicht isoliert, sondern nur im Zusammenhang des gesamten Systems betrachtet werden." (N. Lenke/ H. Lutz/ M. Sprenger 1995: 31).

Możliwe przedstawienie tego zagadnienia znajdujemy u G. Chernova (1995: 224), który pisze: "Any act of communication may be schematically described in the following way: the Speaker produces a message for the benefit of the Listener (the Hearer or Recipient): $\mathrm{S} 1>\mathrm{H} 2 "$.

Nie ulega żadnej wątpliwości, że tak przedstawiony proces komunikacji, choć w swoim założeniu słuszny, jest zdecydowanie niewystarczający, gdyż nie wyczerpuje wszystkich związanych z nią zagadnień. Warto nadmienić choćby proces, który zachodzi, nim w ogóle komunikat zostanie nadany. B.Z. Kielar (1988: 11) przedstawia go w pięciu fazach:

1. Plan komunikacyjny (nadawca planuje nadanie komunikatu),

2. Ideizacja, czyli tworzenie treści w umyśle nadawcy,

3. Rozwinięcie idei, czyli nadanie poszczególnym jej elementom wartości komunikacyjnej,

4. Wyrażenie idei, to znaczy nadawca dobiera odpowiednie wyrażenia i zaczyna tworzyć tekst,

5. Powstanie tekstu (komunikatu).

Pewne rozszerzenie koncepcji G. Chernova proponuje R. Jakobson. W swoim modelu komunikacji porusza on następujące kwestie: nadawca, adresat, komunikat, kontekst, kod oraz kontakt. Jako nadawcę rozumie, co jasne, tego który wysyła komunikat 
do odbiorcy. Ów komunikat musi znajdować się we wspólnym dla nadawcy i odbiorcy kontekście oraz zostać nadany we wspólnym dla nich kodzie, by mogli się oni porozumieć. Ostatnim elementem komunikacyjnej układanki staje się kontakt, który jest fizyczną realizacją komunikatu i umożliwia jej uczestnikom pozostanie w kontakcie (zob. R.Jakobson 1960: 353).

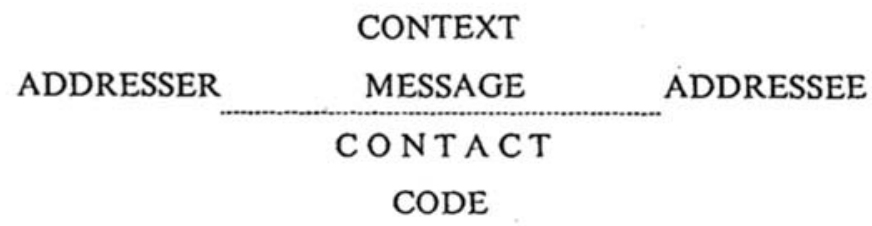

Schemat 5. Schemat komunikacji wg. R. Jakobsona (1960: 353)

Ten schemat, przedstawiony przez R. Jakobsona, wydaje się być pełniejszy od tego przedstawionego wcześniej, jednakże należy zwrócić uwagę na jeden fakt - język jest przez niego traktowany jako byt zupełnie oddzielny od człowieka, jakby znajdował się po za nim, zarówno poza nadawcą, jak i poza odbiorcą.

Podobny model można odnaleźć u K. Sina, który z kolei przedstawia go za Bellem. Różnica polega na tym, iż Bell, przytoczony przez Sina, jasno precyzuje, iż chodzi mu o akt komunikacji monolingwalnej:

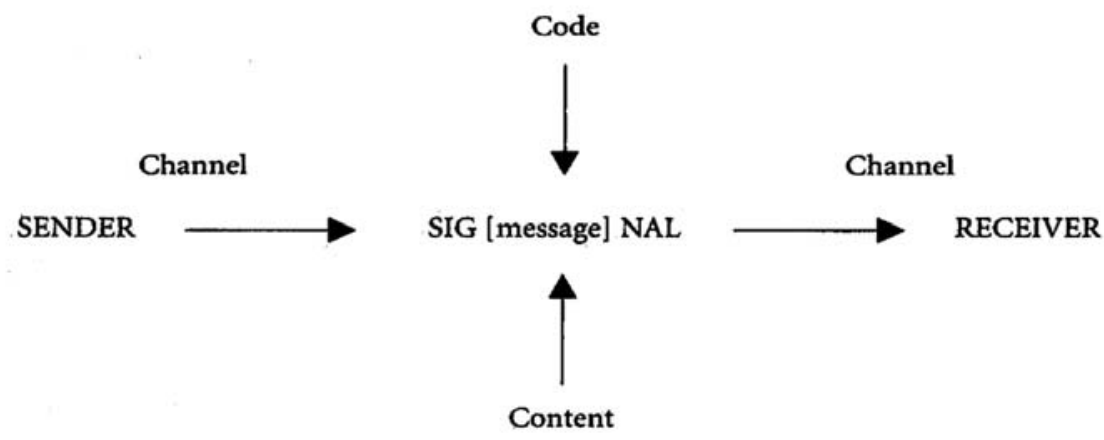

Schemat6. Model komunikacji monolingwalnej Bella (za. K. Sin. 2002: 33)

Powyżej przedstawiony proces można opisać w 9 punktach (zob. K. Sin 2002: 33):

1. Wybór przez nadawcę komunikatu oraz odpowiedniego kodu,

2. Nadawca koduje komunikat,

3. Wybiera odpowiednie medium ${ }^{4}$ komunikacji,

4. Nadawca nadaje sygnał zawierający komunikat,

\footnotetext{
${ }^{4}$ Poprzez „medium” rozumiem sposób w jaki zostanie nadany komunikat. Warto w tym miejscu poczynić także pewne rozróżnienie pojęciowe - komunikacja multimedialna (czyli taka, która wykorzystuje więcej niż jedno medium) nie jest tym samym, co komunikacja mass medialna (komunikacja przy wykorzystaniu tzw. środków masowego przekazu).
} 
5. Odbiorca odbiera sygnał zawierający komunikat,

6. Odbiorca rozpoznaje kod,

7. Odbiorca dekoduje sygnał,

8. Odbiorca odbiera komunikat,

9. Odbiorca dokonuje procesów myślowych polegających na zrozumieniu komunikatu.

W powyższym schemacie oraz jego opisie należy wytknąć pewne nieścisłości. Choć początkowa faza jest zbieżna $\mathrm{z}$ tym, co pisała B.Z. Kielar, to w pierwszej kolejności brakuje wykazania kontekstu, w jakim poruszają się komunikujący się. Po drugie, brak jest, tak samo jak w poprzednich schematach, również bodźca komunikacyjnego. Po trzecie nie zostało tutaj wystarczająco jasno wyjaśnione, czy autor rozumie język, jak jego idealną, modelową reprezentację, czy też jako zinternalizowaną właściwością mówcy-słuchacza. Przypuszczać jedynie można, iż chodzi o ten pierwszy przypadek.

Kolejnym, a zarazem chronologicznie wcześniejszym, modelem komunikacji jest ten zaproponowany przez Shannona i Weavera, a przytoczony przez N. Lenke, H.-D. Lutza i M. Sprengera:

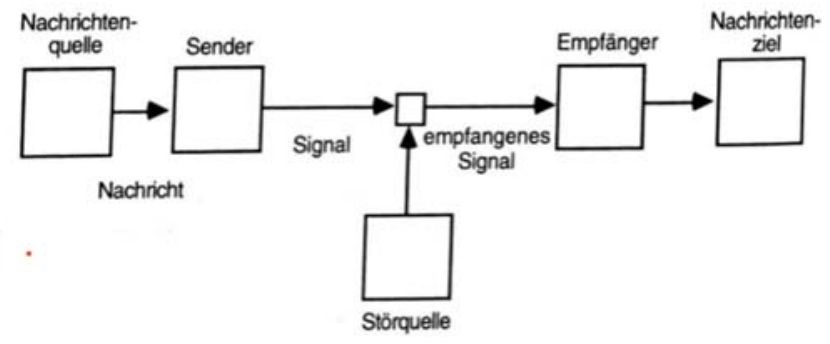

Schemat 7. Model komunikacji Shannon \& Weaver 1949 r. (za N.Lenkeet al.1995: 18)

Przytoczony model jest $\mathrm{z}$ jednej strony słuszny, $\mathrm{z}$ drugiej strony wymaga pewnych uściśleń. Wartym uwagi jest to, iż Shannon i Weaver dostrzegli potrzebę zamieszczenia zewnętrznego źródła, bodźca komunikacyjnego, jednakże nie zauważyli, iż ów bodziec może również wywodzić się z samego nadawcy, może być w nim zinternalizowany. Podobnie to wygląda w przypadku zakłóceń komunikacji - mogą one występować zarówno wewnętrznie (wynikając np. $\mathrm{z}$ wady wymowy nadawcy), jak i zewnętrznie (np. szum uliczny).

Z kolei warto przyjrzeć się modelowi zaproponowanemu przez A. Folkersa i R. Feuerherma:

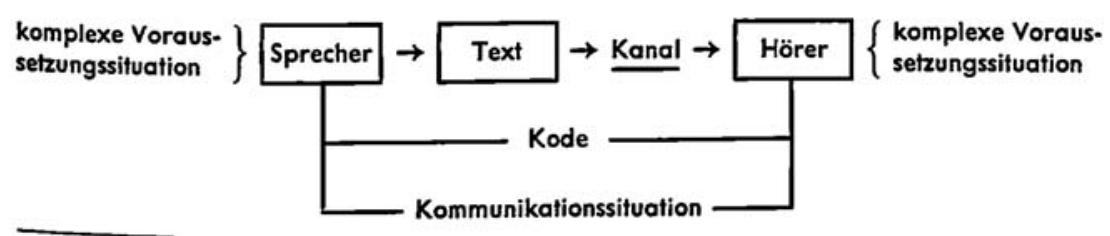

Schemat. 8. SchematkomunikacjiwgA. Folkersa i R. Feuerherma (za A.Folkers 1977: 15)

LingwistykaStosowana/ Applied Linguistics/ AngewandteLinguistik: www.ls.uw.edu.pl 
Ein Sprecher, der zugleich Hörer sein kann, äußert einen Text in einer bestimmten Kommunikationssituation. Dieser Text wird über einen Kanal an den oder die Hörer übermittelt. Damit dieser Text als Träger von Informationen erkannt werden kann, ist es notwendig, dass Sprecher und Hörer über eine gemeinsame Technik der Informationsermittlung und Informationsvermittlung (über einen gemeinsamen Kode) verfügen. Beide stehen außerdem in einem Kontext komplexer Voraussetzungen, die Vorwissen, Bildung, sozio-ökonomische Lage, biographische Situation usw. umfassen (A. Folkers/ R. Feuerherm 1977: 15).

Zgodzić się z nimi należy niewątpliwie w kwestii wzajemności komunikacji - każdy jej uczestnik jest zarówno mówcą, jak i słuchaczem. Niejednokrotnie zdarza się, że wszyscy uczestnicy procesu komunikacji są jednocześnie mówcami i słuchaczami, choć nie można wtedy mówić o skutecznej, czy efektywnej komunikacji, gdyż nie zostaje spełniony jeden z jej warunków: „Efekt komunikacyjny polega na tym, że odbiorca w jakimś stopniu poznał treść myślową, jaką chciał zakomunikować nadawca. W dalszej zaś kolejności może zostać osiągnięty cel komunikacji w formie pożądanych sposobów zachowań u adresatów"(B.Z. Kielar 1988: 12).

A. Badan (1995: 89), powołując się na Spolsky'ego uznaje, iż efektywny proces komunikacji (choć międzykulturowej, ale uwagi przez nich poczynione z powodzeniem mogą odnosić się również do komunikacji międzyludzkiej) nie może mieć miejsca, jeśli zaistnieją następujące przesłanki:

1. Wspólna gramatyka i leksyka,

2. Wspólny system pragmatyczny,

3. Wspólny kontekst fizyczny,

4. Wspólna wiedza o świecie.

By komunikacja mogła zaistnieć, należy spełnić kilka warunków (H. Burger/ B. Imhasly 1978: 17, 19):

(I) Das Verhalten des »Senders« muß intentional sein.

(II) Das Verhalten muß an einen bestimmten Partner (»Adressat«) gerichtet sein.

(III) Das Verhalten muß vom Adressaten wahrgenommen und interpretiert werden.

(IV) Das Verhalten muß symbolisch sein.

(VI)5Kommunikation is dann erfolgreich, wenn das intendierte Verhalten vom Adressaten richtig, d. h. der Intention des Senders gemäß, interpretiert wird.

Odnośnie punktu pierwszego, intencjonalność komunikacji oznacza, iż nadawca ma jakiś cel, powód, by wysyłać komunikat do odbiorcy. Może on być dowolny, ważnym jest fakt, iż takowy istnieje. Jest nim, nawet, podtrzymanie więzi, rozmowy, czy kontaktu $\mathrm{z}$ adresatem.

Eine Handlung ist intentional, insofern sie als vom Handelnden zielgerichtet ausgeführt, erlebt oder legitimiert werden kann bzw. von einem Beobachter in dieser Weise analysiert wird; sie ist funktional, insofern sie in einem supraindividuellen Wirkungszusammenhang eine bestimmte Bedeutung (Funktion) besitzt (S.F. Sager 1981: 12).

Odnośnie punktu drugiego, w przypadku komunikacji międzyludzkiej nie istnieje inna możliwość, jak zwrócić się właśnie do innej osoby, tutaj adresata, choć jak wspo-

${ }^{5}$ Punkt piąty zostanie omówiony poniżej, gdyż nie należy on do warunków, jakie należy spełnić, by komunikacja mogła zaistnieć. 
mniano na początku, człowiek komunikuje się z całym otoczeniem, w którym się w danej chwili znajduje, tak samo, jak to otoczenie komunikuje się z nim.

Odnośnie punktu trzeciego, by komunikacja mogła dojść do skutku - a zatem, jak to nazywa B. Z. Kielar, osiągnięty został efekt i cel komunikacyjny - nadawca musi nadać sygnał w takim kodzie, by odbiorca mógł go zrozumieć, zinternalizować i zinterpretować zgodnie z intencją nadawcy.

Odnośnie punktu czwartego, symboliczność komunikacji opiera się na znakach. „Zastępstwo to [sygnału na znak] opiera się na względnej równowartości tzn. wartość sygnału równa się wartości oznaczonego zjawiska [podkreślenie M.M.], na zasadzie umowy, czyli konwencji społecznej co do zastępstwa" (B.Z. Kielar 1988: 11). Uściślić tutaj należy, iż oznaczone zjawisko równie dobrze może być znakiem drogowym, co wypowiedzianym, czy napisanym słowem. Nie ma znaczenia jakim znakiem zostanie zastąpiony sygnał, o ile jest on zrozumiały dla wszystkich uczestników procesu komunikacji.

Odnośnie punktu szóstego należy zgodzić się z Burgerem i Imhalsy'm w tej kwestii. $\mathrm{Na}$ temat osiągnięcia efektu i celu komunikacyjnego wypowiadała się również B.Z. Kielar. Komunikacja może zostać uznana za efektywną, czy skuteczną, tylko w przypadku kiedy osiągnięty został zamiar komunikacyjny nadawcy, tzn. adresat z powodzeniem otrzymał sygnał w formie znaku, zdekodował go, zrozumiał, a następnie na niego odpowiednio zareagował.

„Wenn (...) keine Interaktion zwischen Partnern stattfindet, findet auch keine Kommunikation statt, selbst wenn das Verhalten intentional ist" (H. Burger/ B. Imhasly 1978: 18). Nie sposób zgodzić się z tym zdaniem, gdyż, jak wykazano powyżej, komunikacja zachodzi nawet $\mathrm{w}$ przypadku, kiedy sygnał $\mathrm{w}$ formie znaku zostanie nadany. $\mathrm{W}$ tym przypadku możemy mówić jedynie o nieosiągniętym efekcie i/ lub celu komunikacji (zob. F. Grucza 1992, 2012b, B.Z. Kielar 1988). H. Burger i B. Imhasly wyróżniają jeszcze sytuację, w której adresat nadaje sygnał w formie znaku, jednakże nie powoduje on werbalnej bądź niewerbalnej reakcji u adresata. Może on powodować reakcję u innego odbiorcy, który z jakiegoś powodu otrzymał, zrozumiał i wykonał zamiar komunikacyjny nadawcy. Taką sytuację określa się mianem fałszywej komunikacji ${ }^{6}$ (zob. H. Burger/ B. Imhasly 1978: 19).

\subsection{Model (rzeczywistej) komunikacji międzyludzkiej}

Na wstępie dokonajmy podsumowania tego, o czym dotychczas była mowa. Inherentną, a jednocześnie zinternalizowaną właściwością konstytutywną każdego człowieka jest jego idiolekt. Język nie jest bytem samodzielnym, który można postrzegać w oddzieleniu od istoty ludzkiej. Samodzielne i, w pewnym sensie, oderwane od człowieka są jedynie idealne, modelowe postacie języka, takie jak np. język polski, rosyjski, czy niemiecki, które powstały na potrzeby usystematyzowania zasad gramatycznych, fonetycznych oraz leksyki, lecz same w sobie są tworami sztucznymi. Rzeczywistym językiem grupy ludzi, czy w tej grupie znajdują się dwie osoby, czy jest ich sto tysięcy, jest polilekt rozumiany jako przekrój logiczny gramatyk i fonemik wszystkich idiolektów składają-

${ }^{6}$ Nazwa polska - M. M. Oryginał niemiecki mówi o „schiefer Kommunikation”. 
cych się na dany polilekt, a także suma logiczna leksyk wszystkich idiolektów składających się na dany polilekt. Polilekty możemy dzielić na etnolekty, socjolekty, profejolekty itp. Wynika z tego dobitnie, że każdy człowiek jest polilektalny - posiada swój własny, indywidualny idiolekt, a także w zależności od wieku, do pewnego stopnia również aequolekt+(od łac. aequus - równy; czyt. polilekt grupy rówieśniczej), topolekt (gr. $\tau$ 兀ođós - miejsce, czyt. polilekt osób mieszkających w tym samym miejscu), profesjolekt (czyt. polilekt grupy specjalistów) itp.

Oprócz swojego indywidualnego idiolektu, człowiek na tej samej zasadzie, na jakiej posiada język, jest również ,posiadaczem” własnej kultury. Idiokultura jest, podobnie jak język, konstytutywną właściwością każdego człowieka. Rzeczywistą kulturą każdej grupy istot ludzkich, niezależnie od jej wielkości, jest polikultura, składająca się z sumy logicznej wszystkich idiokultur. Odróżnić natomiast należy kulturę od znaku kulturowego. Znakiem kulturowym nazywamy wszystkie produkty rzeczywistej kultury ludzkiej. Mogą to być zarówno obrazy, utwory muzyczne, jak i sposób zachowania przy stole, czy ubierania się stosownie do okazji.

Co więcej, każda istota ludzki posiada własną, zinternalizowaną wiedzę, która stanowi jego konstytutywną właściwość. Idiowiedza, bo o niej mowa, jest nabywana przez każdego mówcę-słuchacza poprzez doświadczenie (naturalna idiowiedza), naukę np. w szkole (nabyta idiowiedza), Człowiek posiada również idiowiedzę wrodzoną (genetyczną) oraz idiowiedzę praktyczną (aplikatywną), Z kolei wiedza wspólna danej grupie mówców-słuchaczy stanowi ich poliwiedzę. Poliwiedza to suma logiczna wszystkich rodzajów idiowiedzy składających się na daną poliwiedzę. Podobnie jak w przypadku kultury, należy tutaj odróżnić wiedzę, jako inherentną, zinternalizowaną właściwość konstytutywną każdego, pojedynczego człowieka od znaków wiedzy. Znakiem wiedzy nazwiemy wszystkie wytwory rzeczywistej wiedzy ludzkiej. Mogą to być np. informacje, poszczególne fakty czy fenomeny.

Dokonawszy tego krótkiego podsumowania, możemy teraz przejść do modelu rzeczywistej komunikacji międzyludzkiej:

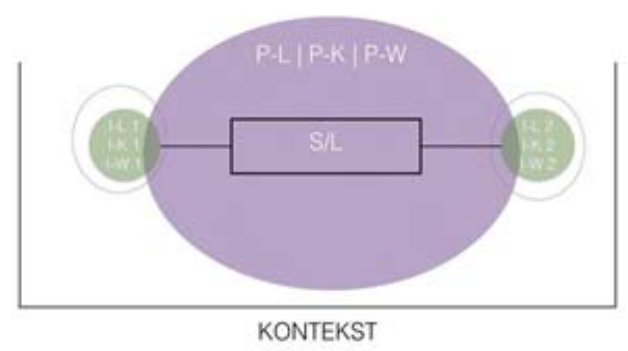

Schemat 9. Uproszczony model rzeczywistej komunikacji międzyludzkiej (S/ L - sygnat lektalny, I-L - idiolekt, I-K-idiokultura, I-W-idiowiedza, $P$-L-polilekt, $P$ - $K$ - polikultura, $P-W$ - poliwiedza)

Powyższy model przedstawia komunikację międzyludzką jedynie w bardzo podstawowym zakresie, dlatego też został nazwany uproszczonym.

Przerywane okręgi oznaczają bodźce komunikacyjne mówców-słuchaczy. Zwykle zakłada się, iż tylko nadawca posiada ów bodziec, jednakże prawda jest taka, iż zarówno mówca, jak i słuchacz oraz słuchacz, jak i mówca (gdyż każdy z uczestników procesu 
komunikacji jest zarówno mówcą, jak i słuchaczem, choć zwykle nie jednocześnie) muszą posiadać odpowiednie bodźce komunikacyjne. Weźmy za przykład rozmowę dwojga znajomych - obojgu powinno zależeć na podtrzymaniu rozmowy, bądź na kontynuowaniu komunikacji. Jeśli choć jedno z nich tego nie uczyni, proces komunikacji międzyludzkiej, co prawda zajdzie, ale będzie niepełny, nieskończony.

Zielone okręgi symbolizują mówców-słuchaczy. Jak przedstawiono powyżej, każdy z nich posiada swój indywidualny idiolekt, idiokulturę i idiowiedzę, które stanowią jegokonstytutywną właściwość. Uczestnik procesu komunikacji po lewej stronie otrzymał numer 1 , zaś ten po prawej numer 2 , celem rozróżnienia ich. Warto również zaznaczyć, że niezależnie od wszystkiego, od tego kim oni są i w jakim celu się komunikują, ich idiolekty/ idiokultury/ idiowiedze nie będą nigdy takie same.

Fioletowym okręgiem zaznaczono polilekt, polikulturę i poliwiedzę uczestników tego procesu komunikacji. Jak wykazano we wcześniejszych częściach niniejszego artykułu, porozumienie pomiędzy dwojgiem mówców-słuchaczy możliwe jest jedynie w momencie, kiedy ich indywidualne idiolekty, idiokultury i idiowiedze są ze sobą, przynajmniej w minimalnej części, zbieżne. Poza tym, polilekt, polikultura oraz poliwiedza, umożliwiają mówcom-słuchaczom wzajemne zrozumienie się ze względu na wykorzystywanie podobnych, bądź identycznych, wytworów idiolektalnych, idiokulturowych i idiowiedzowych.

W czarnym prostokącie, a także poprzez czarne linie, oznaczono sygnał lektalny. Jest on tym samym, co sygnał językowy, parajęzykowy i ekstrajęzykowy jednocześnie. Warto nadmienić, iż ów sygnał nadawany jest w formie znaku (fonemicznego, graficznego, niewerbalnego, itp.). Jeden z uczestników procesu komunikacji, uprzednio konstruując komunikat w taki sposób, jak to opisała B.Z. Kielar (1988), nadaje ów sygnał, zaś drugi go dekoduje, rozumie i odbiera. Następnie, co również zaznaczono przerywanymi liniami, dochodzi albo do osiągnięcia celu i efektu komunikacyjnego, albo nie, w zależności, od tego, czy proces komunikacji był kompletny, czy też nie.

Cała zaś komunikacja odbywa się w pewnym kontekście, w którym znajdują się mówcy-słuchacze. Może to być kontekst danej sytuacji (konstytucja), kontekst przeszły, o którym komunikują mówcy-słuchacze, a także kontekst społeczny i kulturowy. Sam kontekst nie ma znaczenia dla komunikacji, lecz istotnym jest, by oboje jej uczestników znajdowało się w nim jednocześnie i by oboje go rozumieli.

Powyższy model stanowi jedynie uproszczoną wersję komunikacji międzyludzkiej. Przyjrzyjmy się zatem rozszerzonej wersji powyższego modelu:

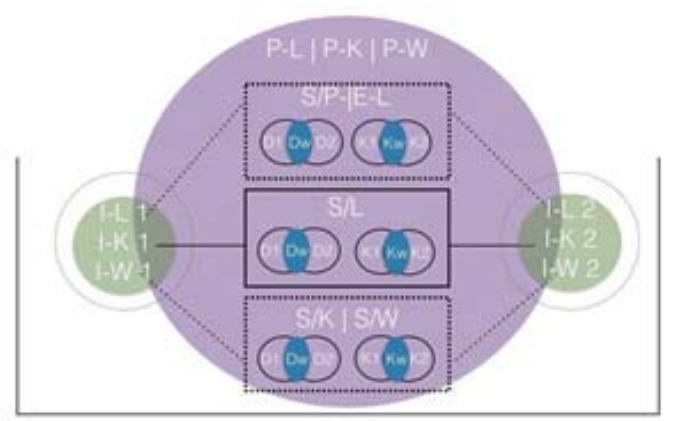

KONTEKST 
Schemat 10. Model rzeczywistej komunikacji międzyludzkiej (S/L-sygnat lektalny, S/ K - sygnat kultury, $S / W$ - sygnat wiedzy, $S / P-L$ - sygnat paralektalny, $S / E-L$ - sygnat ekstralektalny, $D$ - denotat, $K$ - konotat, Dw-denotat wspólny, Kw-konotat wspólny, I-L-idiolekt, I-K-idiokultura, I-W-idiowiedza,

$P$ - L-polilekt, $P$ - $K$ - polikultura, $P$ - $W$ - poliwiedza)

Większość elementów powyższego modelu jest taka sama, jak w przypadku jego uproszczonej wersji - bodźce komunikacyjne zaznaczono przerywanymi liniami, zielone okręgi odzwierciedlają mówców-słuchaczy, fioletowy okrąg pokazuje polilekt/ polikulturę/ poliwiedzę. Kontekst również nie uległ zmianie.

Warto zwrócić uwagę, iż w przeciwieństwie do powyższego, uproszczonego modelu, proces komunikacji stał się on zdecydowanie bardziej skomplikowany. Tym razem sygnał nadawany przez mówcę-słuchacza, a zarazem odbierany przez drugiego uczestnika tego procesu, został podzielony na trzy sygnały, które są odbierane-nadawane jednocześnie.

Mamy tutaj do czynienia z sygnałem lektalnym, jak powyżej, w którego skład wchodzą dodatkowo denotaty lekatalne oraz konopaty lektalne dla obojga mówców-słuchaczy. Mimo że, jak napisano powyżej, porozumienie między dwojgiem mówców słuchaczy możliwe jest jedynie w ramach wspólnego polilektu/ polikultury/ poliwiedzy, to należy wziąć pod uwagę, iż te samy sygnały w formie znakowej mogą stanowić różne denotaty oraz różne konotaty dla każdego z mówców-słuchaczy, a co za tym idzie, mimo wspólnego polilektu/ polikultury/ poliwiedzy, mogą prowadzić do nieporozumień. Dlatego efektywny sygnał lektalny to ten, w ramach którego mówcy-słuchacze posługują się wspólnymi denotatami lektalnymi oraz dekodują wszelkie konotaty lektalne. Do pewnego stopnia możemy tutaj mówić o idiodenotatach oraz idiokonotatach, a także o ich sumie logicznej, tworzącej polikonotaty i polidenotaty.

Oprócz sygnału lektalnego, mówca-słuchacz nadaje również sygnał paralektalny i ekstralektalny, który jest odbierany przez drugiego uczestnika komunikacji. Jeśli obydwoje uczestników procesu komunikacji wywodzą się z tego samego środowiska, jak w przypadku np. topolektu, to w tym momencie denotaty i konotaty ich para- i ekstralektalne nie powinny się znacząco różnić. By zobrazować tę sytuację lepiej, posłużmy się pewnym przykładem: jeśli jeden z mówców-słuchaczy przy powitaniu wyciągnie, zamiast otwartej dłoni skierowanej horyzontalnie w stronę drugiej osoby, zaciśniętą pięść skierowaną horyzontalnie (pot. zw. ̇̇ótwikiem), a jednocześnie podniesie tembr głosu przy werbalizowaniu powitania, wtedy drugi mówca-słuchacz może odebrać oba zachowania para- i ekstralektalne jako familiarne i wyraz ekscytacji ze strony pierwszego z nich (zob. E. Neuland 2008).

Ostatnim elementem powyższego modelu jest sygnał kultury i sygnał wiedzy. Oba te sygnały, choć w swej naturze stanowią odrębne byty, zostały w powyższym schemacie potraktowane jako jeden rodzaj przekazu między dwojgiem mówców-słuchaczy, gdyż niejednokrotnie niezbędna jest wiedza, by dekodować sygnał kultury, jak również niejednokrotnie niezbędna jest kultura, by dekodować sygnał wiedzy. Możemy tutaj mówić o ich przeplataniu się (zob. F. Grucza 1992, 1997). Podobnie, jak w przypadku sygnałów lektalnych, para- i ekstralektalnych, również sygnały kultury i wiedzy mają swoje konotaty i denotaty. Tylko, jak zaproponowano powyżej, na podstawie ich wspólnych, polidenotatów i polikonotatów, możemy mówić o wzajemnym zrozumieniu na poziomie wiedzy i kultury obojga mówców-słuchaczy. 


\section{Podsumowanie}

Jak wykazano w niniejszym artykule, każdy człowiek posiada własny idiolekt, własną idiokulturę, jak również własną idiowiedzę. Wszystkie one stanowią konstytutywne właściwości każdego mówcy-słuchacza i zostały przez niego zinternalizowane. Suma logiczna leksyk dwojga mówców słuchaczy, a także przekrój logiczny ich gramatyk oraz fonemik stanowią ich polilekt. Polilekty możemy dzielić ze względu na miejsce zamieszkania, pracę, szkołę oraz wiele innych kategorii. Najważniejsze jednak jest to, iż każdy człowiek jest polilektalny.

Zaproponowany model (uproszczony) stanowi o rzeczywistej komunikacji międzyludzkiej jedynie w bardzo uproszczony i schematyczny sposób. Z kolei model rzeczywistej komunikacji międzyludzkiej (dla rozróżnienia nazwany rozszerzonym), przedstawia skomplikowanie i ilość procesów zachodzących podczas komunikacji dwojga lub więcej mówców-słuchaczy.

W przedstawionym powyżej przypadku, w procesie rzeczywistej komunikacji międzyludzkiej, bierze udział tylko dwoje mówców-słuchaczy. Model ów może zostać zastosowany także do komunikacji pomiędzy ich większą liczbą. Może on również, w odpowiednio zmodyfikowanej wersji, stanowić podstawę dla stworzenia modelu rzeczywistej komunikacji międzyludzkiej z wykorzystaniem tłumacza.

\section{Bibliografia}

Aitchison, J. (1991), Ssak, który mówi. Warszawa

Ang, I. (2005), Who needs cultural research?, (w:) P. Leistyna (red.), Cultural Studies. Malden, MA/ Oxford/ Carlton, Victoria, 477-482.

Badan, A. (1995), Ethnocultural peculiarities in translation for special purposes, (w:) C. Dollerup/ V. Appel (red.), Teaching Translation and Interpreting 3. Amsterdam/ Philadelphia, 89-93.

Bahadır, SS. (2004), Moving In-Between: The Interpreter as Ethnographer and the Interpreting-Researcher as Anthropologist, (w:) Meta: Journal des traducteurs. Meta:Translators' Journal, 49(4), 805-821.

Bartmiński, J. (2007),Stereotypy mieszkają w języku. Lublin.

Baudouin de Courtenay, J. N. (1974), O zadaniach językoznawstwa. (w:) Jan Niesław Baudouin de Courtenay. Warszawa, 176-201.

Bonacchi, S. (2009), Zur Vieldeutigkeit des Ausdrucks Kultur und zur Anthropozentrischen Kulturtheorie, (w:) KwartalnikNeofilologiczny LVI, 1/ 2009, 25-45.

Bonacchi, S. (2010), Zum Gegenstand der anthropozentrischen Kulturwissenschaft, (w:) Lingwistyka Stosowana/ Applied Linguistics 2/2010, 69-81.

Bonacchi, S. (2012), Interkulturelle Kommunikation, Dialogforschung und Konfliktforschung, (w:) Zeitschrift Des Verbandes Polnischer Gemanisten1, 48-62.

Brückner, A. (1927), Stownik etymologiczny języka polskiego. Kraków.

Burger, H./ B. Imhasly (1978), Formen sprachlicher Kommunikation. München.

Chernov, G. (1995), Taking care of the sense in simultaneous interpreting, (w:) C. Dollerup/ V. Appel (red.), Teaching Translation and Interpreting 3. Amsterdam/ Philadelphia, 223-231. 
Chomsky, N. (1962), Syntactic Structures. S-Gravenhang.

Chomsky, N. (1965), Aspects of the Theory of Syntax. Cambridge, Mass.

Chomsky, N. (1986), Knowledge of Language. New York/ Westport, Conn./ London.

Chomsky, N. (1995), The Minimalist Program. Cambridge, Mass./ London.

Derra, A. (2007), Język i jego problematyczne własności w teorii Noama Chomsky'ego, (w:) Sz. Wróbel (red.),Modularność umysłu. Poznań/ Kalisz, 207-221.

During, S. (2005), Cultural studies. Londyn/ NowyJork.

Floros, G. (2002), Kulturelle Konstellationen in Texten. Tübingen.

Folkers, A./ R. Feuerherm (1977), Sprachliches Handeln 2. Paderborn.

Gorzelańczyk, E. J. (2003), Genetyczne źródła języka, (w:) Scripta Neophilologica Posnaniensa V, 49-54.

Grucza, F. (1992), Kulturowe determinanty języka oraz komunikacji językowej, (w:) F. Grucza (red.), Język, kultura - kompetencja kulturowa. Warszawa, 9-70.

Grucza, F. (1993),Język, ludzkie właściwości językowe, językowa zdolność ludzi, (w:) J. Piontka/ A. Wiercińska (red.), Człowiek w perspektywie ujęć biokulturowych. Poznań, 151-174.

Grucza, F. (1996), Wyodrębnianie się, stan aktualny i perspektywy świata translacji oraz translatoryki, (w:) J. Snopek (red.), Tłumaczenie. Warszawa, 10-45.

Grucza, F. (1997), Języki ludzie a wyrażenia językowe, wiedza a informacja, mózg a umyst ludzki,(w:) F. Grucza/ M. Dakowska (red.), Podejścia kognitywne w lingwistyce, translatoryce i glottodydaktyce. Warszawa, 7-21.

Grucza, F. (2000), Kultur aus der Sicht der Angewandten Linguistik, (w:) H.D. Schlosser (red.), Forum Angewandte Linguistik vol. 38. Frankfurt am Main, 17-29.

Grucza, F. (2002), Język - tożsamość - integracja europejska (w:) E. Jeleń/ M. Rauen/ M. Świątek/ J. Winiarska (red.), Zmiany i rozwój języka w tożsamości narodowej. Kraków, 25-49.

Grucza, F. (2012a),Kulturologia antropocentryczna a kulturoznawstwo, (w:) K. Grzywka (red.), Kultura - Literatura - Język. Warszawa, 79-102.

Grucza, F. (2012b). Zum Gegenstand un zu den Aufgaben der anthropozentrischen Linguistik, Kulturologie und Kommunikologie sowie zur gegenseitingen Vernetzung dieser Erkenntnisbereiche, (w:) Kwartalnik Neofilologiczny LIX (3/ 2012), 287344.

Grucza, S. (2010), Gtówne tezy antropocentrycznej teorii języków, (w:) Lingwistyka Stosowana 2/ 2010, 1-28.

Grucza, S. (2012c),Lingwistyka antropocentryczna a badania okulograficzne, (w:) Lingwistyka Stosowana 4/ 2011, 149-162.

Jakobson, R. (1960), Closing statement: Linguistics and poetics, (w:) T.A. Sebeok (red.), Style in Language. Cambrigde, Mass,350-377.

Kielar, B.Z. (1988), Ttumaczenie i koncepcje translatoryczne. Warszawa.

Lenke, N./ H.-D. Lutz/ M. Sprenger (1995), Grundlagen sprachlicher Kommunikation. München.

Linz, E. (2002), Indiskrete Semantik. Kognitivie Linguistik und neurowissenschaftliche Theoriebildung. München.

Markus H./ Hamedani M. (2007), Sociocultural Psychology: The Dynamic Interdependence among SelfSystems and Social Systems, (w:) S. Kitayama/ D. Cohen (red.), 
Handbook of Cultural Psychology.New York, 3-39.

Neuland, E. (2008), Jugendsprache - Jugendliteratur - Jugendkultur: interdisziplinäre Beiträge zu sprachkulturellen Ausdrucksformen Jugendlicher. Frankfurt am Main.

Pinker, S. (2002), The Blank State. London.

Roth, G. (1996), Das Gehirn und seine Wirklichkeit: Neurobiologie und ihre pgilosophischen Konsequenzen. Frankfurt am Main

Roth, G. (2003), Fühlen, Denken, Handlen: Wie das Gehirn unser Verhalten steuert. Frankfurt am Main.

Sager, S. F. (1981), Sprache und Beziehung. Tübingen.

Sapir, E. (1978), Kultura, język, osobowość. Warszawa.

Sin, K.-K. (2002). Myths and misconceptions in translation teaching, (w:) E. Hung (red.), Teaching translation and interpreting 4. Amsterdam/ Philadelphia, 31-43.

Whorf, B. L. (1982),Język, myśl, rzeczywistość. Warszawa.

Wierzbicka, A. (1991),Uniwersalne pojęcia ludzkie i ich konfiguracja w różnych kulturach, (w:) Etnolingwistyka 4, 7-39. 